\title{
Effects of walking and strength training on walking capacity in individuals with claudication: meta-analysis
}

\author{
Efeitos do treinamento de caminhada e força na capacidade \\ de caminhada de claudicantes: meta-análise
}

\begin{abstract}
Alessandra de Souza Miranda', Lausanne Barreto de Carvalho Cahú Rodrigues', Sérgio Luiz Cahú Rodrigues', Crivaldo Gomes Cardoso Júnior², Maryela Oliveira Menacho³, Diego Giulliano Destro Christofaro ${ }^{3}$, Raphael Mendes Ritti-Dias ${ }^{1}$
\end{abstract}

\begin{abstract}
Context: Over the past few years, several clinical trials have been performed to analyze the effects of exercise training on walking ability in patients with intermittent claudication (IC). However, it remains unclear which type of physical exercise provides the maximum benefits in terms of walking ability. Objective: To analyze, by means of a meta-analysis, the effects of walking and strength training on the walking capacity in patients with IC. Methods: Papers analyzing the effects of walking and strength training programs in patients with IC were browsed on the Medline, Lilacs, and Cochrane databases. Randomized clinical trials scoring >4 on the Physiotherapy Evidence Database (PEDro) scale and assessing claudication distance (CD) and total walking distance (TWD) were included in the review. Results: Walking and strength training yielded increases in CD and TWD $(P<0.05)$. However, walking training yielded greater increases than strength training $(P=0.02)$. Conclusion: Walking and strength training improve walking capacity in patients with IC. However, greater improvements in TWD are obtained with walking training.
\end{abstract}

Keywords: exercise; vascular diseases; peripheral arterial disease.

\begin{abstract}
Resumo
Contexto: Ao longo dos últimos anos, diversos ensaios clínicos têm sido realizados sobre os efeitos do treinamento físico na capacidade de caminhada de pacientes com claudicação intermitente (Cl). No entanto, ainda permanece incerto, qual modalidade de treinamento físico promove maiores aumentos na capacidade de caminhada dos pacientes. Objetivo: Analisar, por meio de meta-análise, os efeitos do treinamento de caminhada e de força na capacidade de locomoção de pacientes com Cl. Métodos: Foi realizada pesquisa bibliográfica de artigos que analisaram os efeitos do treinamento de caminhada e de força em pacientes com Cl nas bases de dados Medline, Lilacs e Cochrane. Foram incluídos na revisão estudos clínicos randomizados com escore $>4$ na escala de PEDro e que quantificaram a distância de claudicação (DC) e a distância total de caminhada (DTC). Resultados: Os treinamentos de caminhada e de força promoveram aumentos na DC e na DTC $(P<0,05)$. No entanto, os aumentos obtidos com o treinamento de caminhada foram superiores aos obtidos com o treinamento de força $(P=0,02)$. Conclusão: $O s$ treinamentos de caminhada e de força promovem aumento na capacidade de locomoção de pacientes com Cl. No entanto, efeitos na DTC são mais acentuados com o treinamento de caminhada.
\end{abstract}

Palavras-chave: exercício; doenças vasculares; doença arterial periférica.

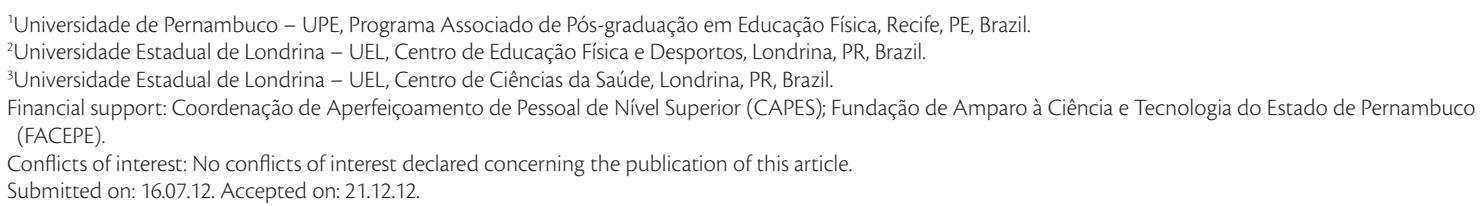

Submitted on: 16.07.12. Accepted on: 21.12.12. 


\section{INTRODUCTION}

Peripheral artery disease (PAD), one of the main atherosclerotic diseases, is associated with high morbidity rates among the elderly ${ }^{1}$. The main symptom of PAD is intermittent claudication (IC), characterized by pain in the lower limbs, particularly the calf, when walking ${ }^{2}$. The prevalence of PAD is $3 \%$ to $10 \%$ in the general population and about $20 \%$ in the population older than 70 years ${ }^{3,4}$.

IC is the cause of limitations to walking, which may compromise the performance of physical activities of daily living 5 . In addition, individuals with IC have muscle atrophy and decreased muscle strength $^{6}$, power and resistance in the lower limbs ${ }^{7}$. Supervised physical training combined with changes in life style has proven to be important interventions for the treatment of individuals with $\mathrm{IC}^{8}$, and significant increases in their walking ability and muscle and skeletal aptitudes have been found ${ }^{9,10}$.

Currently, there is evidence that supports the use of walking training in patients with $\mathrm{PAD}^{11}$. In fact, improvements in fitness and quality of life have been found, in addition to the fact that training is low cost and easy to perform ${ }^{12-14}$. Recent studies showed that strength training also improves fitness and quality of life of patients with $\mathrm{PAD}^{10,15-18}$. However, it is still unclear which of the two modalities of physical training results in greater increases in walking capacity.

This study conducted a meta-analysis to compare the effects of walking and strength training on the walking capacity of individuals with IC.

\section{METHODS}

\section{Literature review}

The MedLine, Lilacs and Cochrane databases were reviewed. First, studies were selected according to their publication date, which was limited to July 1980 to December 2010.

For the search, keywords in Portuguese and their corresponding keywords in English were selected using the DECS and the MeSH databases. The keywords selected were: exercício físico/ physical exercise, aptidão física/fitness, caminhadal walking, treinamento de força/strength training and claudicação intermitente/intermittent claudication. For the selection of studies, combinations of keywords were used for the search. As a result, 1947 studies were retrieved, but only eight ${ }^{15-17,19-23}$ met inclusion criteria. Figure 1 shows the flowchart of study selection in this meta-analysis.

First, two authors read the study titles to check whether they met the purposes of this meta-analysis. When no decision was reached after reading the title, the abstract and later, if necessary, the whole study was read. This meta-analysis included studies that: (i) were randomized clinical trials; (ii) included a sample of individuals with PAD and symptoms of IC; (iii) analyzed the effects of supervised physical training (walking or strength); (iv) measured claudication distance (CD) or total walking distance (TWD) before and after the intervention; (v) included more than one experimental group; and (vi) had a score equal to or greater than 4 on the Physiotherapy Evidence Database (PEDro) scale, used to measure the quality of methods in clinical studies.

\section{Data extraction}

The following data were extracted from the studies that met inclusion criteria: (a) publication year; (b) groups; (c) number of individuals in each group; (d) type of physical exercises; (e) duration of intervention; (f) frequency (times a week); (g) volume of training session; (h) method used to measure intensity; (i) intensity prescribed; (j) initial CD or TWD; (k) final CD or TWD.

\section{Data analysis}

Mean and standard deviation values were calculated according to mean values in the studies to describe the characteristics of individuals included in the study. For inferential analysis, mean difference and $95 \%$ confidence intervals were calculated; the fixed effects model was used when results were homogeneous ( $\mathrm{P} \leq 0.10)$; and a random effects model was used when results were heterogeneous $(\mathrm{P}<0.10)$. The Review Manager 5.1 software was used for all analyses.

\section{RESULTS}

\section{Study quality}

Mean PEDro score of the studies included was $5.5 \pm 0.9$, and scores ranged from 4 to 7 (Table 1 ). The factors that lowered scores in a relevant way were: participant distribution was not blinded ${ }^{15-17,20,22,23}$; participant assignment to intervention groups was not blinded ${ }^{15-17,19-23}$; the individuals that administered the training program were not blinded ${ }^{15-17,19-23}$; and statistical analysis did not follow intention to treat $^{15-17,19-23}$. 


\section{Study characteristics}

Of a total of 424 individuals included, 238 underwent physical training (Table 2). Most participants were men (65\%) and elderly (67 \pm 4 years). The duration of PAD described in four studies $^{15,20,22,23}$ was $3.4 \pm 0.8$ years. All individuals included in the study had mild to moderate IC, and mean ankle-brachial index $(\mathrm{ABI})$ was $0.64 \pm 0.06$.

Body mass (BM) was described in four studies $^{15,19,21,23}$, and mean BM was $76.0 \pm 4.9 \mathrm{~kg}$; body mass index (BMI) was found in three studies ${ }^{16,19,23}$, and mean BMI was $28.6 \pm 2.0 \mathrm{~kg} / \mathrm{m}^{2}$. The analysis of comorbidities revealed that four studies ${ }^{15,17,19,22}$ described the presence of hypertension, five $\mathrm{e}^{15,17,19,21,22}$, heart disease, four ${ }^{16,17,19,21}$, diabetes, and two ${ }^{15,22}$, dyslipidemia. In addition, most studies ${ }^{15-17,19-22}$ reported that individuals were smokers.

\section{Walking ability before intervention}

$\mathrm{CD}$ was reported in eight studies ${ }^{15-17,19-23}$. Mean CD before intervention was $203 \pm 126 \mathrm{~m}$ and $197 \pm 124 \mathrm{~m}$ in the studies that used walking and strength training. In all studies, $\mathrm{CD}$ was similar between experimental and control groups before intervention.
Mean TWD before intervention was $365 \pm 182 \mathrm{~m}$ and $329 \pm 171 \mathrm{~m}$ in the studies that used walking and strength training. In all studies, TWD was similar between experimental and control groups before intervention.

\section{Training program}

Duration ranged from $\operatorname{six}^{23}$ to $48^{19}$ weeks, and 12 weeks was the most frequent duration ${ }^{15,17,20,22}$. Frequency ranged from $\mathrm{two}^{17}$ to three times a week ${ }^{15-}$ ${ }^{17,19-23}$, whereas session length ranged from 20 to 60 minutes ${ }^{15-17,19-23}$.

Walking training was prescribed according to perception of exertion, with Borg scores ranging

Table 1. Quality of studies included in meta-analysis.

\begin{tabular}{cc}
\hline Study & Score \\
\hline Crowther $^{19}$ & $5 / 10$ \\
Hiatt $^{15}$ & $5 / 10$ \\
McDermott $^{16}$ & $7 / 10$ \\
Mika $^{20}$ & $6 / 10$ \\
Parr $^{23}$ & $4 / 10$ \\
Ritti-Dias $^{17}$ & $6 / 10$ \\
Sanderson $^{21}$ & $6 / 10$ \\
Tsai $^{22}$ & $5 / 10$ \\
\hline
\end{tabular}

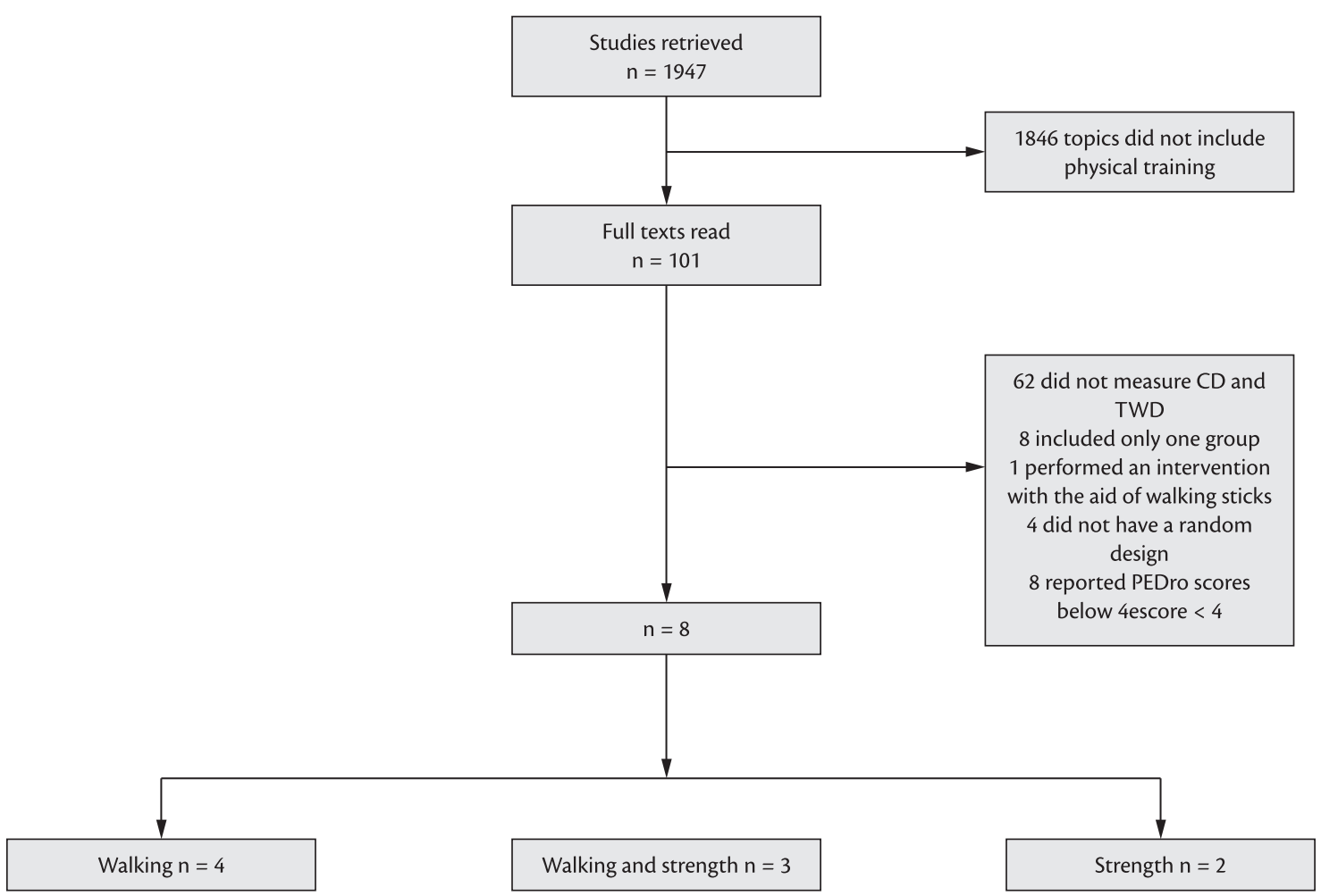

Figure 1. Flowchart of inclusion of studies in the meta-analysis CD - claudication distance; TWD - total walking distance. 
Table 2. Characteristics of the studies that met inclusion criteria.

\begin{tabular}{|c|c|c|c|c|}
\hline Study & Intervention & Subjects (n) & Duration (weeks) & Frequency (week) \\
\hline \multirow[t]{2}{*}{ Crowther ${ }^{19}$} & Treadmill walking & 10 & 48 & 3 \\
\hline & Control & 11 & 48 & - \\
\hline \multirow[t]{3}{*}{ Hiatt $^{15}$} & Strength & 9 & 12 & 3 \\
\hline & Treadmill walking & 10 & 12 & 3 \\
\hline & Control & 10 & 12 & - \\
\hline \multirow[t]{2}{*}{ McDemort $^{16}$} & Strength & 52 & 24 & 3 \\
\hline & Treadmill walking & 51 & 24 & 3 \\
\hline Mika ${ }^{20}$ & Treadmill walking & 27 & 12 & 3 \\
\hline Control & & 28 & 12 & - \\
\hline \multirow[t]{2}{*}{ Parr $^{23}$} & Strength & 9 & 6 & 3 \\
\hline & Control & 8 & 6 & - \\
\hline \multirow[t]{2}{*}{ Ritti-Dias ${ }^{17}$} & Strength & 15 & 12 & 2 \\
\hline & Treadmill walking & 15 & 12 & 2 \\
\hline \multirow[t]{2}{*}{ Sanderson ${ }^{21}$} & Treadmill walking & 13 & 6 & 3 \\
\hline & Control & 14 & 6 & - \\
\hline \multirow[t]{2}{*}{ Tsai $^{22}$} & Treadmill walking & 27 & 12 & 3 \\
\hline & Control & 26 & 12 & - \\
\hline
\end{tabular}

from 11 to $14^{16,17}$, and perception of claudication pain, with scores ranging from 3 to $4^{19}$. Peak oxygen consumption (peak $\mathrm{VO}_{2}$ ) was used in one study, at an intensity of $80 \%$ of peak $\mathrm{VO}_{2}^{21}$.

Strength training was prescribed according to perception of exertion, with Borg scores ranging from 11 to $13^{16,17}$, and tests of $6^{15}$ and $15^{23}$ maximum repetitions.

\section{Effects of training on walking ability}

The comparison of the effects of walking training and control intervention on $\mathrm{CD}$ (Table 3) revealed that only walking training significantly increased CD (152 m; 95\% CI [135, 168], $P<0.00001)$. The comparison of the effects of strength training and control intervention on $\mathrm{CD}$ revealed that only strength training significantly increased CD $(17 \mathrm{~m}$; 95\% CI $[-27,61], P=0.03)$. The comparison of increases of $\mathrm{CD}$ in walking and strength training revealed that the effects of the two trainings were similar $(P=0.32)$.

The comparison of the effects of walking training and control intervention on TWD ${ }^{15,16,20-22}$ (Table 4) revealed that only walking training significantly increased TWD (173 m; 95\% CI [56, 290], $P<$ 0.00001). Also, the comparison of the effects of strength training and control intervention on TWD revealed that only strength training significantly increased TWD (106 m; 95\% CI [33, 180] $P=0.005)$. However, the increase in TWD as a result of walking training was greater $(P=0.02)$ than that obtained after strength training.

\section{DISCUSSION}

This study compared the effects of walking training and strength training on the walking capacity of individuals with IC using data in the literature. For that purpose, a meta-analysis was conducted. Results showed that: (i) walking and strength training increased the walking capacity of patients with IC; (ii) the effects of strength and walking training on $\mathrm{CD}$ are similar; (iii) walking training resulted in greater TWD increases than strength training.

Most studies included in this meta-analysis used walking training ${ }^{15-17,19-22}$. This may be partly explained by the fact that several Vascular Surgery Associations $^{8,11}$, in their official guidelines, recommend walking as the most important exercise for patients with PAD. Recent recommendations have included strength training as part of training for individuals with PAD, although only a few studies using strength training have been published. In fact, our analysis included only four studies that evaluated the effects of strength training on the walking ability of patients with $\mathrm{PAD}^{15-17,23}$. Furthermore, one of these studies had a weight greater than $70 \%$ in the metaanalysis because of the high number of individual included in its sample. Therefore, further studies about this topic should be conducted.

The effects of walking and strength training on CD were similar, but TWD increased more after 


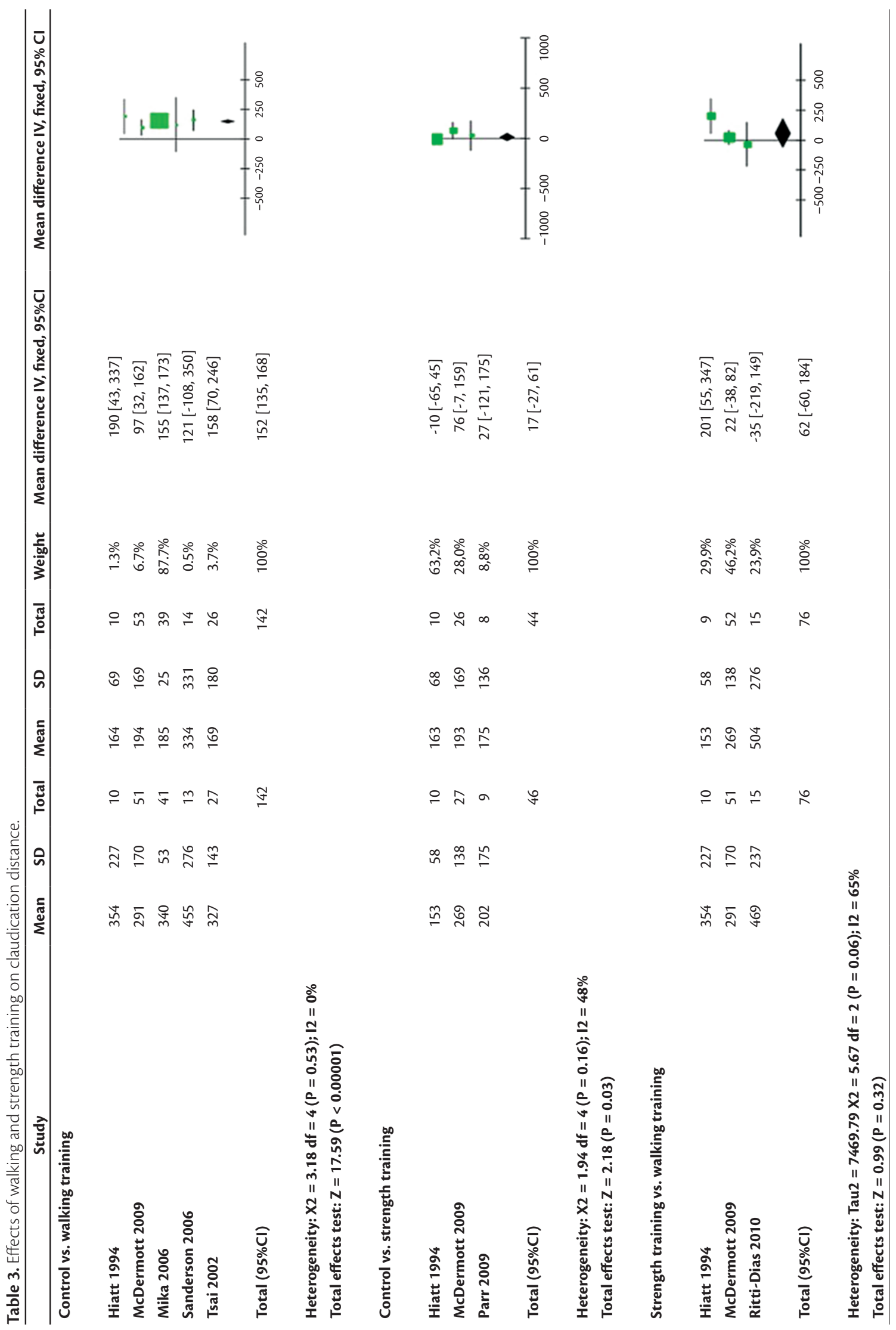




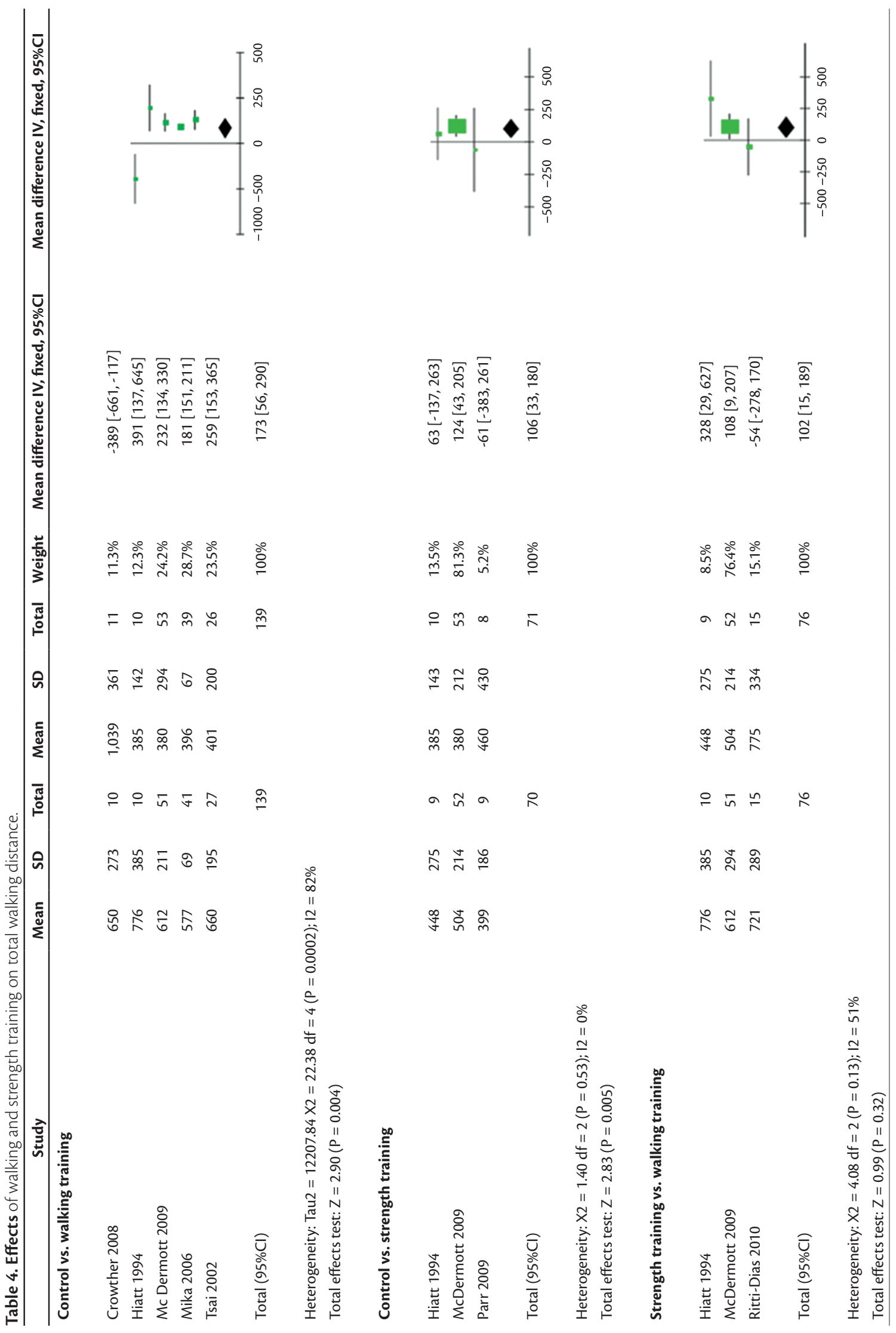


walking training. This can be explained by the fact that the mechanisms of increase in walking ability differ between walking and strength training. The increases in walking ability after walking training have been assigned to: angiogenesis ${ }^{24}$; improvement of endothelial function; increase of oxidative enzyme concentrations ${ }^{13}$; and improvement of walking efficiency. In contrast, the increases obtained with strength training have been basically assigned to angiogenesis and improvements on walking efficiency. Therefore, the effects of walking training on oxidative metabolism seem to explain the differences between the effects of walking and strength training on the walking ability of patients with PAD.

One of the limitations of this study was the inclusion of studies only in Portuguese or English. Another important aspect was the fact that, although only studies that measured walking ability using treadmills were included, there was some variation in the protocols used. Therefore, results between studies should be compared cautiously. However, individual studies used the same protocol to measure walking ability, and we were, therefore, able to assess the effects of training between groups.

\section{CONCLUSION}

Walking and strength training improve the walking capacity of patients with PAD, but walking training results in greater increases of TWD.

\section{REFERENCES}

1. Wang J, Zhou S, Bronks R, Graham J, Myers S. Effects of supervised treadmill-walking training on strength and endurance of the calf muscles of individuals with peripheral arterial disease. Clin J Sport Med. 2006;16:397-400. PMid:17016115. http://dx.doi. org/10.1097/01.jsm.0000244604.70542.b2

2. Dormandy JA, Rutherford RB. Management of peripheral arterial disease (PAD). TASC Working Group. TransAtlantic Inter-Society Consensus (TASC). J Vasc Surg. 2000;31:S1-S296. PMid:10666287.

3. Criqui MH, Fronek A, Barrett-Connor E, Klauber MR, Gabriel S, Goodman D. The prevalence of peripheral arterial disease in a defined population. Circulation. 1985;71:510-5. PMid:3156006. http://dx.doi.org/10.1161/01.CIR.71.3.510

4. Selvin E, Erlinger TP. Prevalence of and risk factors for peripheral arterial disease in the United States: results from the National Health and Nutrition Examination Survey, 1999-2000. Circulation. 2004;110:738-43. PMid:15262830. http://dx.doi. org/10.1161/01.CIR.0000137913.26087.F0

5. Regensteiner JG, Steiner JF, Hiatt WR. Exercise training improves functional status in patients with peripheral arterial disease. J Vasc Surg. 1996;23:104-15. http://dx.doi.org/10.1016/ S0741-5214(05)80040-0
6. Regensteiner JG, Wolfel EE, Brass EP, et al. Chronic changes in skeletal muscle histology and function in peripheral arterial disease. Circulation. 1993;87:413-21. PMid:8425290. http://dx.doi. org/10.1161/01.CIR.87.2.413

7. Gerdle B, Hedberg B, Angquist KA, Fugl-Meyer AR. Isokinetic strength and endurance in peripheral arterial insufficiency with intermittent claudication. Scand J Rehabil Med. 1986;18:9-15. PMid:3715429.

8. Norgren L, Hiatt WR, Dormandy JA, et al. Inter-society consensus for the management of peripheral arterial disease. Int Angiol. 2007;26:81-157. PMid:17489079.

9. Hodges LD, Sandercock GR, Das SK, Brodie DA. Randomized controlled trial of supervised exercise to evaluate changes in cardiac function in patients with peripheral atherosclerotic disease. Clin Physiol Funct Imaging. 2008;28:32-7. PMid:18005078.

10. McGuigan MR, Bronks R, Newton RU, et al. Resistance training in patients with peripheral arterial disease: effects on myosin isoforms, fiber type distribution, and capillary supply to skeletal muscle. J Gerontol A Biol Sci Med Sci. 2001;56:B302-10 PMid:11445595. http://dx.doi.org/10.1093/gerona/56.7.B302

11. Hirsch AT, Haskal ZJ, Hertzer NR, et al. ACC/AHA 2005 Practice Guidelines for the management of patients with peripheral arterial disease (lower extremity, renal, mesenteric, and abdominal aortic) a collaborative report from the American Association for Vascular Surgery/Society for Vascular Surgery, Society for Cardiovascular Angiography and Interventions, Society for Vascular Medicine and Biology, Society of Interventional Radiology, and the ACC/ AHA Task Force on Practice Guidelines (Writing Committee to DevelPMid:16549646.op Guidelines for the Management of Patients With Peripheral Arterial Disease): endorsed by the American Association of Cardiovascular and Pulmonary Rehabilitation; National Heart, Lung, and Blood Institute; Society for Vascular Nursing; TransAtlantic Inter-Society Consensus; and Vascular Disease Foundation. Circulation. 2006;113:e463-654.

12. Alpert JS, Larsen OA, Lassen NA. Exercise and intermittent claudication. Blood flow in the calf muscle during walking studied by the xenon-133 clearance method. Circulation. 1969;39:353-9. PMid:4885945. http://dx.doi.org/10.1161/01.CIR.39.3.353

13. Dahllof AG, Bjorntorp P, Holm J, Schersten T. Metabolic activity of skeletal muscle in patients with peripheral arterial insufficiency. Eur J Clin Invest. 1974;4:9-15. PMid:4819838. http://dx.doi. org/10.1111/j.1365-2362.1974.tb00365.x

14. Dahllof AG, Holm J, Schersten T, Sivertsson R. Peripheral arteria insufficiency, effect of physical training on walking tolerance, calf blood flow, and blood flow resistance. Scand J Rehabi Med. 1976;8:UNKNOWN.

15. Hiatt WR, Wolfel EE, Meier RH, Regensteiner JG. Superiority of treadmill walking exercise versus strength training for patients with peripheral arterial disease. Implications for the mechanism of the training response. Circulation. 1994;90:1866 74. PMid:7923674. http://dx.doi.org/10.1161/01.CIR.90.4.1866

16. McDermott MM, Ades P, Guralnik JM, et al. Treadmill exercise and resistance training in patients with peripheral arterial disease with and without intermittent claudication: a randomized controlled trial. JAMA. 2009;301:165-74. PMid:19141764 PMCid:3268032. http://dx.doi.org/10.1001/jama.2008.962

17. Ritti-Dias RM, Wolosker N, De Moraes Forjaz CL, et al. Strength training increases walking tolerance in intermittent claudication patients: randomized trial. J Vasc Surg. 2010;51:8995. PMid:19837534. http://dx.doi.org/10.1016/j.jvs.2009.07.118 
18. Wang E, Helgerud J, Loe H, Indseth K, Kaehler N, Hoff J. Maximal strength training improves walking performance in peripheral arterial disease patients. Scand J Med Sci Sports. 2010;20(5):764-70. PMid:19804581. http://dx.doi. org/10.1111/j.1600-0838.2009.01014.x

19. Crowther RG, Spinks WL, Leicht AS, Sangla K, Quigley F, Golledge $J$. Effects of a long-term exercise program on lower limb mobility, physiological responses, walking performance, and physical activity levels in patients with peripheral arterial disease. J Vasc Surg 2008;47:303-9. PMid:18241753. http://dx.doi.org/10.1016/j. jvs.2007.10.038

20. Mika P, Spodaryk K, Cencora A, Mika A. Red blood cell deformability in patients with claudication after pain-free treadmill training. Clin J Sport Med. 2006;16:335-40. PMid:16858218. http:// dx.doi.org/10.1097/00042752-200607000-00009

21. Sanderson B, Askew C, Stewart I, Walker P, Gibbs H, Green S. Short-term effects of cycle and treadmill training on exercise tolerance in peripheral arterial disease. J Vasc Surg. 2006;44:11927. PMid:16828435. http://dx.doi.org/10.1016/j.jvs.2006.03.037

22. Tsai JC, Chan P, Wang CH, et al. The effects of exercise training on walking function and perception of health status in elderly patients with peripheral arterial occlusive disease. J Intern Med. 2002;252:448-55. PMid:12528763. http://dx.doi. org/10.1046/j.1365-2796.2002.01055.x

23. Parr BM, Noakes TD, Derman EW. Peripheral arterial disease and intermittent claudication: efficacy of short-term upper body strength training, dynamic exercise training, and advice to exercise at home. S Afr Med J. 2009;99:800-4. PMid:20218480.

24. Schlager $O$, Giurgea A, Schuhfried $O$, et al. Exercise training increases endothelial progenitor cells and decreases asymmetric dimethylarginine in peripheral arterial disease: a randomized controlled trial. Atherosclerosis. 2011;217:240-8. PMid:21481871. http://dx.doi.org/10.1016/j.atherosclerosis.2011.03.018
Correspondence Raphael Mendes Ritti Dias ESEF-UPE

Rua Arnóbio Marques, 310, Santo Amaro CEP 50100-130 - Recife (PE), Brazi Fone: (81) 3183-3375/(81) 9728-6878 E-mail: raphaelritti@gmail.com

Author information ASM, LBCCR holds a MSc degree from Universidade de Pernambuco (UPE).

SLCR is a PhD candidate at Graduate Program in Physical Education, UPE/UFPB

CGC holds a PhD degree from Universidade de São Paulo (USP). MOM holds a MSc degree from Universidade Estadual de Londrina (UEL).

DGDC holds a PhD degree from Universidade Estadual de Londrina (UEL)

RMR holds a PhD degree from Universidade de São Paulo (USP).

Author contributions Conception and design: RMRD, ASM, LBCCR, SLCR Analysis and interpretation: RMR, CGCJ, DGDC, MOM

Data collection: ASM, LBCCR Writing the article: RMRD, ASM

Critical revision of the article: $L A B C R, C G C$ J, SLCR, DGDC, MOM Final approval of the article*: ASM, LBCCR, SLCR, CGC), MOM

DGDC, RR

Statistical analysis: DGDC, MOM Overall responsibility: RMRD

*All authors should have read and approved of the final version of the article submitted to J Vasc Bras. 